\title{
Functional analysis using chlortetracycline fluorescence and in vitro fertilization of frozen-thawed ejaculated boar spermatozoa incubated in a protein-free chemically defined medium
}

\author{
W. H. Wang ${ }^{1}$, L. R. Abeydeera ${ }^{1 *}$, L. R. Fraser ${ }^{2}$ and K. Niwa ${ }^{1 \dagger}$ \\ ${ }^{1}$ Division of Animal Science and Technology, Faculty of Agriculture, Okayama University, \\ Okayama 700, Japan; and ${ }^{2}$ Anatomy and Human Biology Group, Biomedical Sciences Division, \\ King's College London, Strand, London WC2R 2LS, UK
}

\begin{abstract}
Cumulus-enclosed pig oocytes were matured in vitro, freed from cumulus cells, and inseminated with frozen-thawed ejaculated spermatozoa in a chemically defined protein-free medium containing $37.0 \mathrm{mmol} \mathrm{NaHCO} \mathrm{l}^{-1}$ and $5 \mathrm{mmol}$ caffeine $\mathrm{l}^{-1}$. When the medium was supplemented with $1 \mathrm{mg}$ polyvinylalcohol (PVA) $\mathrm{ml}^{-1}$, more penetrated oocytes were observed $14 \mathrm{~h}$ after insemination with $7-12 \times 10^{6} \mathrm{cells} \mathrm{ml}^{-1}$ than with $4-5 \times 10^{6}$ cells $\mathrm{ml}^{-1}$ and the incidence of polyspermy reflected the sperm concentration used. Varying the $\mathrm{NaHCO}_{3}$ concentration but maintaining the sperm concentration at $8 \times 10^{6} \mathrm{cells}_{\mathrm{s}} \mathrm{ml}^{-1}$ resulted in significantly more oocytes being penetrated in media containing 45.83-50.25 than $37.0-41.42 \mathrm{mmol} \mathrm{NaHCO}_{3} \mathrm{l}^{-1}$; there were no significant differences in the incidence of either male pronuclear formation or polyspermy. In medium containing $45.83 \mathrm{mmol}$ $\mathrm{NaHCO}_{3} 1^{-1}$, the inclusion of PVA at $0-5 \mathrm{mg} \mathrm{ml}^{-1}$ had no effect on proportions of penetrated oocytes, male pronuclear formation or polyspermy. However, when spermatozoa from three different boars were evaluated, the penetration and male pronuclear formation rates were highly variable, unlike the incidence of polyspermy. Penetration of cumulus-free oocytes was first detected at $6 \mathrm{~h}$. When spermatozoa were incubated for $6 \mathrm{~h}$ in the absence of oocytes, motility, but not vitality, decreased whether or not PVA was included in the medium. Chlortetracycline (CTC) fluorescence analysis of the capacitation state indicated a rapid decline in the proportion of live uncapacitated, acrosome-intact cells and a rapid rise in the proportion of live capacitated, acrosome-reacted cells during the first hour. Smaller changes in the distribution of CTC patterns occurred during the later stages, suggesting that the rapidly responding cells were non-fertilizing, owing to damage by freeze-thawing, and that the fertilizing spermatozoa were drawn from the remaining pool of cells which underwent capacitation more slowly. This is the first report indicating that capacitation of frozen-thawed ejaculated boar spermatozoa and penetration of oocytes matured in culture are possible in a chemically defined, protein-free medium.
\end{abstract}

\section{Introduction}

Many successful systems for in vitro fertilization of pig oocytes matured in vivo or in vitro with fresh ejaculated or epididymal boar spermatozoa have been developed. In all of these, fertilization media contain a proteinaceous macromolecule such as bovine serum albumin (BSA; e.g., Yoshida et al., 1993) and fetal calf serum (FCS; e.g., Funahashi and Day, 1993a). Medium containing BSA or FCS has also been shown to support successful in vitro fertilization of pig oocytes with frozen-thawed epididymal (Nagai et al., 1988; Kikuchi et al., 1993) and ejaculated (Wang et al., 1991; Zheng

*Present address: Department of Animal Science, University of MissouriColumbia, Columbia, MO 65211, USA

${ }^{+}$Reprint requests.

Received 6 February 1995. et al., 1992) spermatozoa. In other mammals, including hamsters (Bavister, 1982), mice (Fraser, 1985), and cattle (Tajik et al., 1993), penetration of oocytes in vitro has proved possible in media without protein when cumulus-enclosed oocytes were inseminated. Although no studies have examined rigorously whether such proteins are necessary for inducing boar sperm capacitation and penetration of oocytes in vitro, a recent study by Funahashi and Day (1993b) indicated that penetration rates of cumulus-enclosed pig oocytes with fresh ejaculated spermatozoa are lower in a protein-free fertilization medium ( $\mathrm{pH}$ 7.4). Experiments using frozen-thawed ejaculated spermatozoa indicated that the $\mathrm{pH}$ of the medium influences penetration rates in vitro of cumulus-free pig oocytes: FCS-containing medium at $\mathrm{pH} 7.8$ (Wang et al., 1994) supports higher penetration rates than does the same medium at $\mathrm{pH} 7.4$ (Wang et al., 1992). 
These various results suggest that a chemically defined, protein-free medium with a raised $\mathrm{pH}$ might provide a suitable environment for successful capacitation and fertilization. The present study was designed to investigate this possibility using frozen-thawed ejaculated spermatozoa. To optimize conditions, several parameters including the concentration of spermatozoa, $\mathrm{NaHCO}_{3}$, and the protein substitute polyvinylalcohol (PVA) were evaluated. In addition, chlortetracycline (CTC) analysis was performed to assess capacitation of spermatozoa incubated in the medium with optimized conditions. The CTC fluorescence technique, first used by Ward and Storey (1984) to assess the functional status of mouse spermatozoa, has been used to monitor capacitation and acrosomal exocytosis in mouse (Fraser and McDermott, 1992), human (DasGupta et al., 1993) and bovine (Fraser et al., 1995) spermatozoa.

\section{Materials and Methods}

\section{Media}

The basic medium, designated TCM-199B ( $\mathrm{pH} 7.4$ ), used for the maturation of oocytes was tissue culture medium (TCM) 199 (with Earle's salts; Gibco, Grand Island, NY) supplemented with $3.05 \mathrm{mmol}$ glucose $\mathrm{I}^{-1}, 2.92 \mathrm{mmol}$ calcium lactate $\mathrm{I}^{-1}$, $0.91 \mathrm{mmol}$ sodium pyruvate $\mathrm{l}^{-1}, 75 \mu \mathrm{g}$ potassium penicillin $\mathrm{G}$ $\mathrm{ml}^{-1}, 50 \mu \mathrm{g}$ streptomycin sulfate $\mathrm{ml}^{-1}$ and $10 \%(\mathrm{v} / \mathrm{v})$ heat inactivated FCS (Gibco). This medium was exactly the same as that used by Wang et al. (1991). The basic medium used for the treatment of spermatozoa and the fertilization of oocytes was essentially the same as that used by Brackett and Oliphant (1975) for the fertilization of rabbit oocytes in vitro, except that BSA, phenol red and penicillin $G$ were deleted from the medium. This medium, designated modified $\mathrm{BO}(\mathrm{mBO})$ medium, consisted of $112.0 \mathrm{mmol} \mathrm{NaCl} \mathrm{l}{ }^{-1}, 4.02 \mathrm{mmol} \mathrm{KCl}$ $1^{-1}, 2.25 \mathrm{mmol} \mathrm{CaCl}_{2} \mathrm{I}^{-1}, 0.83 \mathrm{mmol} \mathrm{NaH}_{2} \mathrm{PO}_{4} \mathrm{l}^{-1}$, $0.52 \mathrm{mmol} \mathrm{MgCl} \mathrm{I}^{-1}, 37.0 \mathrm{mmol} \mathrm{NaHCO}_{3} \mathrm{l}^{-1}, 13.9 \mathrm{mmol}$ glucose $1^{-1}$ and $1.25 \mathrm{mmol}$ sodium pyruvate $\mathrm{I}^{-1}$. In experiments in which the concentration of $\mathrm{NaHCO}_{3}$ was increased to $41.42-50.25 \mathrm{mmol} \mathrm{l}^{-1}$, the calculated osmolarity of the medium was always maintained at about 330 mosmol by changing the concentration of $\mathrm{NaCl}$.

\section{Preparation of oocytes}

Ovaries were collected from maturing gilts at a local abattoir and transported to the laboratory within $1.0-1.5 \mathrm{~h}$ in $0.9 \%$ $(\mathrm{w} / \mathrm{v}) \mathrm{NaCl}$ containing $75 \mu \mathrm{g}$ potassium penicillin $\mathrm{G} \mathrm{ml}^{-1}$ and $50 \mu \mathrm{g}$ streptomycin sulfate $\mathrm{ml}^{-1}$ at $37-39^{\circ} \mathrm{C}$. Oocytes were aspirated from antral follicles (2-5 $\mathrm{mm}$ in diameter) with an 18-gauge needle fixed to a $10 \mathrm{ml}$ disposable syringe and washed four times with the maturation medium, TCM-199B supplemented with $10 \mathrm{iu}$ equine chorionic gonadotrophin $\mathrm{ml}^{-1}$ (Serotropin: Teikoku-Zoki Co., Tokyo), 10 iu hCG ml ${ }^{-1}$ (Puberogen: Sankyo Co., Tokyo) and $1 \mu \mathrm{g}$ oestradiol $\mathrm{ml}^{-1}$ (Sigma Chemical Co., St Louis, MO). Ten oocytes surrounded by compact cumulus were transferred to a $100 \mu \mathrm{l}$ drop of the same medium which had previously been covered with warm paraffin oil in a polystyrene culture dish $(35 \mathrm{~mm} \times 10 \mathrm{~mm}$;
Becton Dickinson Labware, Lincoln Park, NJ) and equilibrated in an atmosphere of $5 \% \mathrm{CO}_{2}$ in air for about $3 \mathrm{~h}$, and cultured for $36 \mathrm{~h}$ at $39^{\circ} \mathrm{C}$ under the same atmospheric conditions. After culture, oocytes were freed from cumulus and corona cells by treatment with TCM-199B containing $0.1 \%(\mathrm{w} / \mathrm{v})$ hyaluronidase from bovine testis (Sigma) followed by repeated passage through a fine pipette. The denuded oocytes were then washed twice with $\mathrm{mBO}$ medium containing $10 \mathrm{mmol}$ caffeine-sodium benzoate $\mathrm{l}^{-1}$ (Sigma) and 0-10 $\mathrm{mg}$ polyvinylalcohol (PVA) $\mathrm{ml}^{-1}$, and 5-7 oocytes were placed into a $50 \mu \mathrm{l}$ drop of the same medium covered with warm paraffin oil in a culture dish $(35 \mathrm{~mm} \times 10 \mathrm{~mm})$. The dishes were kept in a $\mathrm{CO}_{2}$ incubator $\left(5 \% \mathrm{CO}_{2}\right.$ in air at $\left.39^{\circ} \mathrm{C}\right)$ for about $30 \mathrm{~min}$ until spermatozoa were added for fertilization.

\section{Sperm preparation and in vitro fertilization}

Spermatozoa were prepared as described by Wang et al. (1991), except that mBO medium rather than TCM-199B was used as the fertilization medium. Briefly, three $0.1 \mathrm{ml}$ pellets of frozen ejaculated spermatozoa obtained from boars of proved fertility were thawed in $2 \mathrm{ml}$ of $\mathrm{mBO}$ medium at $37^{\circ} \mathrm{C}$ for about $1 \mathrm{~min}$. The medium had been previously equilibrated in an atmosphere of $5 \% \mathrm{CO}_{2}$ in air for about $3 \mathrm{~h}$. After thawing, spermatozoa were washed three times in the same medium by centrifugation at $550 \mathrm{~g}$ for $5 \mathrm{~min}$. The sperm pellet was then resuspended to give a sperm concentration of $8-24 \times 10^{6}$ cells $\mathrm{ml}^{-1}$. A $50 \mu \mathrm{l}$ aliquot of final sperm suspension was introduced into $50 \mu \mathrm{l}$ of $\mathrm{mBO}$ medium containing the oocytes and gametes were incubated at $39^{\circ} \mathrm{C}$ in $5 \% \mathrm{CO}_{2}$ in air. The final concentration of caffeine was always $5 \mathrm{mmol} \mathrm{l}^{-1}$ based on earlier work (Wang et al., 1991), but those of $\mathrm{NaHCO}_{3}$, PVA and spermatozoa were varied according to the different experiments as detailed below.

\section{Examination of oocytes for sperm penetration}

At $14 \mathrm{~h}$ after insemination, oocytes were mounted, fixed for $48-72 \mathrm{~h}$ in $25 \%(\mathrm{v} / \mathrm{v})$ acetic acid in ethanol at room temperature, stained with $1 \%(\mathrm{w} / \mathrm{v})$ orcein in $45 \%(\mathrm{v} / \mathrm{v})$ acetic acid and examined under a phase-contrast microscope at a magnification of $\times 200$ and $\times 400$. Oocytes were considered to be penetrated when they had a swollen sperm head(s) or male pronucleus(ei) and the corresponding sperm tail(s). When polyspermic oocytes contained at least one male pronucleus, they were classified as penetrated oocytes at the pronuclear stage.

\section{Chlortetracycline assessment of spermatozoa}

The methods used to prepare spermatozoa for CTC assessment were essentially the same as those described by Fraser et al. (1995) for bull spermatozoa. Briefly, $4 \mu \mathrm{l}$ Hoechst solution, containing $100 \mu \mathrm{g}$ Hoechst bis-benzimide $33258 \mathrm{ml}^{-1}$ (Sigma) in $\mathrm{mBO}$ medium with $37.0 \mathrm{mmol} \mathrm{NaHCO}_{3} 1^{-1}$, was added to $396 \mu \mathrm{l}$ sperm suspension. After mixing and gently vortexing, the suspension was incubated for $3 \mathrm{~min}$ at room temperature in the dark, layered onto $4 \mathrm{ml}$ of $3 \%(\mathrm{w} / \mathrm{v})$ polyvinylpyrrolidone (PVP-40; Sigma) in PBS and centrifuged 
at $500 \mathrm{~g}$ for $6 \mathrm{~min}$. The pelleted spermatozoa were resuspended in $50 \mu \mathrm{l}$ of the same $\mathrm{mBO}$ medium. From this suspension, $45 \mu \mathrm{l}$ was added to $45 \mu \mathrm{l} \mathrm{CTC}$ solution, and after mixing, $8 \mu \mathrm{l}$ of $12.5 \%(\mathrm{w} / \mathrm{v})$ paraformaldehyde in $0.5 \mathrm{~mol}$ Tris- $\mathrm{HCl}$ $1^{-1}$ ( $\mathrm{pH} \mathrm{7.4)}$ was added with mixing. The CTC solution was prepared daily by adding $750 \mu \mathrm{mol}$ CTC $1^{-1}$ (Sigma) and $5 \mathrm{mmol}$ cysteine $\mathrm{I}^{-1}$ (Sigma) to a buffer containing $130 \mathrm{mmol}$ $\mathrm{NaCl} \mathrm{l}^{-1}$ and $20 \mathrm{mmol}$ Tris $\mathrm{l}^{-1}$ (Trizma base: Sigma); the $\mathrm{pH}$ was adjusted to 7.8 .

Slides were prepared by placing $10 \mu \mathrm{l}$ of the fixed sperm suspension on a slide and one drop of $0.22 \mathrm{~mol}$ 1,4-diazabicyclo[2.2.2] octane $1^{-1}$ (Sigma) dissolved in glycerol: PBS (9:1) was mixed in carefully to retard the fading of fluorescence. A coverslip was added and excess fluid was removed by compressing the slide and coverslip. Slides were sealed with colourless nail varnish and spermatozoa were assessed under a phase-contrast microscope (Diaphot-TMD IS Nikon), equipped with epifluorescent optics, on the same day. When observed under ultraviolet illumination (excitation at $330-380 \mathrm{~nm}$, emission at $420 \mathrm{~nm}$ ), spermatozoa showing no staining of the nucleus were considered to be alive. Live spermatozoa were then observed under blue-violet illumination (excitation at $400-440 \mathrm{~nm}$, emission at $470 \mathrm{~nm}$ ) and classified according to CTC staining patterns.

The same basic patterns of fluorescent staining observed in mouse (Fraser and McDermott, 1992), human (DasGupta et al., 1993) and bull (Fraser et al., 1995) spermatozoa were seen in boar spermatozoa. The three patterns identified were: F: with uniform fluorescence over the whole head; $B$ : with fluorescence-free band in the postacrosomal region; AR: with almost no fluorescence over the whole head except for a thin band of fluorescence in the equatorial segment. Typical examples of these patterns are shown in Fig. 1.

\section{Statistical analyses}

The proportions of penetrated oocytes, pronuclear formation and polyspermy in Expts 1-5, and those of motile and live spermatozoa as well as spermatozoa showing different CTC patterns in Expt 6, were subjected to arc-sine transformation; the transformed values were assigned for one-way (Expts I-4 and 6) and two-ways (Expt 5) ANOVA. When ANOVA revealed a significant treatment effect, values were compared by Duncan's multiple-range test.

\section{Experimental Details and Results}

\section{Experiment 1: effect of sperm concentration}

Cumulus-free oocytes were placed in a $50 \mu \mathrm{l}$ droplet of $\mathrm{mBO}$ medium containing $37.0 \mathrm{mmol} \mathrm{NaHCO}_{3} \mathrm{l}^{-1}, 10 \mathrm{mmol}$ caffeine $1^{-1}$ and $2 \mathrm{mg} \mathrm{PVA} \mathrm{ml}^{-1}$. For insemination, $50 \mu \mathrm{l}$ of sperm

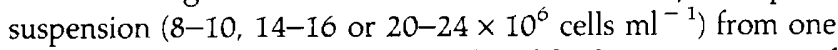
boar (OKA-5) was added. This produced final concentrations of $4-5,7-8$ or $10-12 \times 10^{6}$ spermatozoa $\mathrm{ml}^{-1}, 5 \mathrm{mmol}$ caffeine $\mathrm{l}^{-1}, 37.0 \mathrm{mmol} \mathrm{NaHCO}_{3} \mathrm{l}^{-1}$ and $1 \mathrm{mg} \mathrm{PVA} \mathrm{ml}{ }^{-1}$. Four replicate experiments were performed $(n=4)$.
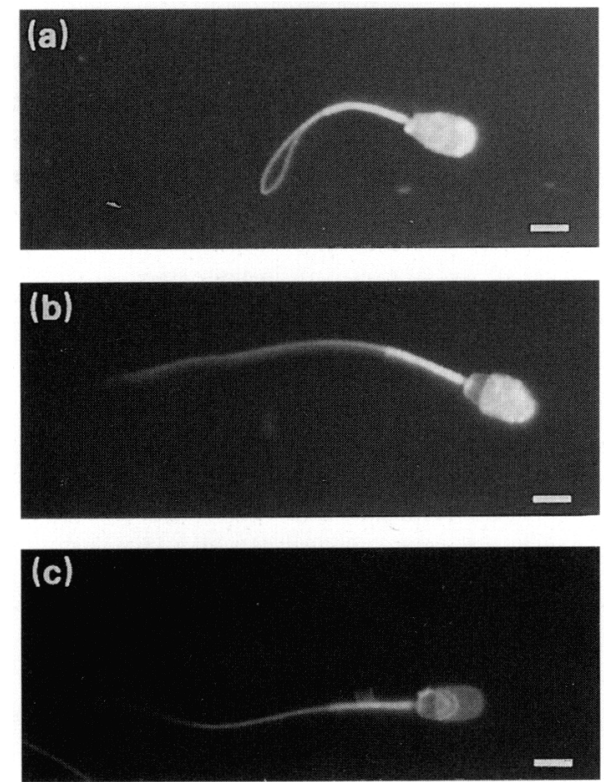

Fig. 1. Three patterns of chlortetracycline fluorescence staining observed on boar spermatozoa cultured in a chemically defined medium (mBO medium) containing $45.83 \mathrm{mmol} \mathrm{NaHCO}_{3} \mathrm{l}^{-1}$. $5 \mathrm{mmol}$ caffeine $\mathrm{l}^{-1}$ and $1 \mathrm{mg}$ PVA $\mathrm{ml}^{-1}$ : (a) F, with uniform fluorescence over the whole head; (b) B, with a fluorescence-free band in the post-acrosomal region; (c) AR, with dull fluorescence over the whole head except for the thin and bright band of fluorescence in the equatorial segment. Scale bars represent $4 \mu \mathrm{m}$.

The proportion of penetrated oocytes was significantly higher $(P<0.05)$ when the sperm concentration was increased from $4-5 \times 10^{6} \mathrm{cells} \mathrm{ml}^{-1}\left(28 \%\right.$ penetrated) to $7-8 \times 10^{6}$ cells $\mathrm{ml}^{-1}(45 \%)$; no further increase in penetration rate was observed with $10-12 \times 10^{6}$ spermatozoa $\mathrm{ml}^{-1}$ (Table 1). The incidence of polyspermy increased as the sperm concentration increased, the difference being significant $(P<0.05)$ with $10-12 \times 10^{6}$ cells $\mathrm{ml}^{-1}$ ( $49 \%$ polyspermic oocytes) compared with $4-5 \times 10^{6}$ cells ml ${ }^{-1}(21 \%)$. There was no significant difference in the proportions $(31-39 \%)$ of pronuclear formation among different sperm concentrations.

\section{Experiment 2: effect of $\mathrm{NaHCO}_{3}$ concentration}

Cumulus-free oocytes were introduced into a $50 \mu \mathrm{l}$ droplet of $\mathrm{mBO}$ medium containing $10 \mathrm{mmol}$ caffeine $\mathrm{l}^{-1}, 2 \mathrm{mg}$ PVA $\mathrm{ml}^{-1}$, and concentrations of $\mathrm{NaHCO}_{3}$ adjusted to 37.0, 45.83, 54.66 and $63.50 \mathrm{mmol} \mathrm{l}^{-1}$. For insemination, $50 \mu \mathrm{l}$ of sperm suspension (boar OKA-5) in $\mathrm{mBO}$ medium with $37.0 \mathrm{mmol}$ $\mathrm{NaHCO}_{3} \mathrm{l}^{-1}$ was added to give a final sperm concentration of $8 \times 10^{6}$ cells ml $\mathrm{ml}^{-1}$. This resulted in final concentrations of $\mathrm{NaHCO}_{3}$ of $37.0,41.42,45.83$ and $50.25 \mathrm{mmol} \mathrm{l}^{-1}, 5 \mathrm{mmol}$ caffeine $\mathrm{I}^{-1}$, and $1 \mathrm{mg}$ PVA ml ${ }^{-1}$. The $\mathrm{pH}$ of the medium at introduction of oocytes was $7.7 \pm 0.03(n=4)$.

Significantly higher $(P<0.05)$ proportions of oocytes were penetrated when fertilization medium contained $\mathrm{NaHCO}_{3}$ at concentrations of $45.83-50.25$ (74-76\% penetrated) than $37.0-$ $41.42(37-51 \%) \mathrm{mmol}^{-1}$ (Table 2). However, the proportions of both pronuclear $(32-41 \%)$ and polyspermic $(39-54 \%)$ oocytes were similar in all groups. 
Table 1. Effect of sperm concentration on penetration of cumulus-free pig oocytes by frozen-thawed ejaculated spermatozoa from boar OKA-5 in a chemicaily defined medium ${ }^{a}$

\begin{tabular}{|c|c|c|c|c|c|}
\hline \multirow[b]{2}{*}{$\begin{array}{l}\text { Sperm } \\
\text { concentration } \\
\left(\times 10^{6} \mathrm{ml}^{-1}\right)\end{array}$} & \multirow[b]{2}{*}{$\begin{array}{l}\text { Number of } \\
\text { oocytes } \\
\text { inseminated }\end{array}$} & \multicolumn{3}{|c|}{ Number of oocytes penetrated ${ }^{b}$} & \multirow{2}{*}{$\begin{array}{c}\text { Number of } \\
\text { polyspermic } \\
\text { oocytes } \\
(\%)^{c}\end{array}$} \\
\hline & & Total $(\%)$ & $\begin{array}{l}\text { With swollen } \\
\text { sperm head }\end{array}$ & $\begin{array}{l}\text { With male and } \\
\text { female pronuclei } \\
(\%)^{c}\end{array}$ & \\
\hline $4-5$ & 50 & $14(28)^{d}$ & 10 & $4(31)$ & $3(21)^{d}$ \\
\hline $7-8$ & 85 & $38(45)^{\mathrm{e}}$ & 24 & $14(37)$ & $13(34)^{\mathrm{de}}$ \\
\hline $10-12$ & 85 & $37(44)^{e}$ & 23 & $14(39)$ & $18(49)^{\mathrm{e}}$ \\
\hline
\end{tabular}

Table 2. Effect of $\mathrm{NaHCO}_{3}$ concentration on penetration of cumulus-free pig oocytes by frozen-thawed ejaculated spermatozoa from boar OKA-5 in a chemically defined medium ${ }^{\mathrm{a}}$

\begin{tabular}{|c|c|c|c|c|c|}
\hline \multirow[b]{2}{*}{$\begin{array}{l}\text { Concentration } \\
\text { of } \mathrm{NaHCO}_{3} \\
\left(\mathrm{mmol} \mathrm{I}^{-1}\right)^{-1}\end{array}$} & \multirow[b]{2}{*}{$\begin{array}{l}\text { Number of } \\
\text { oocytes } \\
\text { inseminated }\end{array}$} & \multicolumn{3}{|c|}{ Number of oocytes penetrated ${ }^{b}$} & \multirow{2}{*}{$\begin{array}{c}\text { Number of } \\
\text { polyspermic } \\
\text { oocytes } \\
(\%)^{c}\end{array}$} \\
\hline & & Total $(\%)$ & $\begin{array}{l}\text { With swollen } \\
\text { sperm head }\end{array}$ & $\begin{array}{l}\text { With male and } \\
\text { female pronuclei } \\
(\%)^{c}\end{array}$ & \\
\hline 37.00 & 76 & $28(37)^{\mathrm{d}}$ & 19 & $9(32)$ & $11(39)$ \\
\hline 41.42 & 80 & $41(51)^{\mathrm{d}}$ & 25 & $16(39)$ & $17(41)$ \\
\hline 45.83 & 70 & $53(76)^{\mathrm{e}}$ & 34 & $19(36)$ & $23(43)$ \\
\hline 50.25 & 83 & $61(74)^{\mathrm{e}}$ & 36 & $25(41)$ & $33(54)$ \\
\hline
\end{tabular}

${ }^{a}$ The fertilization medium (mBO medium) contained $1 \mathrm{mg} \mathrm{PVA} \mathrm{ml}^{-1}$ and $5 \mathrm{mmol}$ caffeine $1^{-1}$, and final sperm concentration was $8 \times 10^{6}$ cells $\mathrm{ml}^{-1}(n=4)$.

bocytes were examined $14 \mathrm{~h}$ after insemination.

'Percentage of penetrated oocytes.

${ }^{d e} V$ alues with different superscripts within each column differ significantly $(P<0.05)$.

\section{Experiment 3: effect of PVA concentration}

Cumulus-free oocytes were introduced into a $50 \mu \mathrm{l}$ droplet of $\mathrm{mBO}$ medium containing $45.83 \mathrm{mmol} \mathrm{NaHCO}_{3} \mathrm{l}^{-1}$, $10 \mathrm{mmol}$ caffeine $\mathrm{I}^{-1}$ and $0-10 \mathrm{mg}$ PVA $\mathrm{ml}^{-1}$. For insemination, $50 \mu \mathrm{l}$ sperm suspension (from boar OKA-5) in the same medium without caffeine and PVA was added to give a sperm concentration of $8 \times 10^{6} \mathrm{cells} \mathrm{ml}^{-1}$. This resulted in final concentrations of $5 \mathrm{mmol}$ caffeine $1^{-1}, 45.83 \mathrm{mmol} \mathrm{NaHCO}$ $1^{-1}$ and $0-5 \mathrm{mg} \mathrm{PVA} \mathrm{ml}^{-1}(n=3)$.

There were no significant differences in the proportions of penetrated $(78-81 \%)$, pronuclear $(27-41 \%)$, and polyspermic $(32-52 \%)$ oocytes in media containing different concentrations $\left(0-5 \mathrm{mg} \mathrm{ml}^{-1}\right)$ of PVA (Table 3). However, when PVA was not present in the medium, oocytes became very sticky and frequently disappeared during washing before introducing them into fertilization medium for insemination. For this reason, PVA was included in the following protocol.

\section{Experiment 4: comparison of sperm suspension from three boars}

The penetration of cumulus-free oocytes by spermatozoa $\left(8 \times 10^{6}\right.$ cells $\left.\mathrm{ml}^{-1}\right)$ from three different boars (OKA-3, L-4 and
OKA-5) was compared using $\mathrm{mBO}$ medium with final concentrations of $45.83 \mathrm{mmol} \mathrm{NaHCO} \mathrm{l}^{-1}, 5 \mathrm{mmol}$ caffeine $\mathrm{l}^{-1}$ and $1 \mathrm{mg}$ PVA $\mathrm{ml}^{-1}(n=3)$.

High penetration rates were observed with spermatozoa from boar OKA-3 $(81 \%)$ and OKA-5 $(81 \%)$, but a significantly lower $(P<0.05)$ rate $(40 \%)$ was obtained with boar L-4 (Table 4). Differences were also observed in the proportions of pronuclear oocytes; there were significantly higher $(P<0.05)$ rates with spermatozoa from boars OKA-3 $(55 \%)$ and L-4 $(54 \%)$ than from boar OKA-5 $(24 \%)$, but no differences in the incidence of polyspermy were detected.

Experiment 5: kinetics of penetration using cumulus-free and cumulus-enclosed oocytes

After maturation culture for $36 \mathrm{~h}$, a portion of oocytes remained intact. The protocol detailed in Expt 4 was used and cumulus-enclosed and cumulus-free oocytes were separately inseminated with spermatozoa from boar OKA-5 $\left(8 \times 10^{6}\right.$ cells $\mathrm{ml}^{-1}$ ) and examined 2, 4, 6, 8, 10, 12 and $14 \mathrm{~h}$ after insemination for evidence of sperm penetration. Cumulusenclosed oocytes were freed from cumulus and corona cells 
Table 3. Effect of concentration of polyvinylalcohol (PVA) on penetration of cumulus-free pig oocytes by frozen-thawed ejaculated spermatozoa from boar OKA-5 in a chemically defined medium ${ }^{\mathrm{a}}$

\begin{tabular}{|c|c|c|c|c|c|}
\hline \multirow[b]{2}{*}{$\begin{array}{l}\text { Concentration } \\
\text { of PVA } \\
\left(\mathrm{mg} \mathrm{ml}{ }^{-1}\right)\end{array}$} & \multirow[b]{2}{*}{$\begin{array}{c}\text { Number of } \\
\text { oocytes } \\
\text { inseminated }\end{array}$} & \multicolumn{3}{|c|}{ Number of oocytes penetrated } & \multirow{2}{*}{$\begin{array}{c}\text { Number of } \\
\text { polyspermic } \\
\text { oocytes } \\
(\%)^{c}\end{array}$} \\
\hline & & Total $(\%)$ & $\begin{array}{l}\text { With swollen } \\
\text { sperm head }\end{array}$ & $\begin{array}{c}\text { With male } \\
\text { and female } \\
\text { pronuclei }(\%)^{c}\end{array}$ & \\
\hline 0 & 80 & $64(80)$ & 47 & $17(27)$ & $33(52)$ \\
\hline 0.1 & 50 & $39(78)$ & 26 & $13(33)$ & $16(41)$ \\
\hline 1.0 & 52 & $42(81)$ & 25 & $17(41)$ & $15(36)$ \\
\hline 2.0 & 50 & $40(80)$ & 24 & $16(40)$ & $14(35)$ \\
\hline 5.0 & 49 & $38(78)$ & 25 & $13(34)$ & $12(32)$ \\
\hline
\end{tabular}

${ }^{a}$ The fertilization medium (mBO medium) contained $45.83 \mathrm{mmol} \mathrm{NaHCO}_{3} \mathrm{I}^{-1}$ and $5 \mathrm{mmol}$ caffeine $\mathrm{I}^{-1}$, and final sperm concentration was $8 \times 10^{\circ}$ cells ml $^{-1}(n=3)$.

'Oocytes were examined $14 \mathrm{~h}$ after insemination.

${ }^{c}$ Percentage of penetrated oocytes.

Table 4. Penetration of cumulus-free pig oocytes by spermatozoa from three different boars in a chemically defined medium ${ }^{a}$

\begin{tabular}{|c|c|c|c|c|c|}
\hline \multirow[b]{2}{*}{ Boar } & \multirow[b]{2}{*}{$\begin{array}{c}\text { Number of } \\
\text { oocytes } \\
\text { inseminated }\end{array}$} & \multicolumn{3}{|c|}{ Number of oocytes penetrated } & \multirow{2}{*}{$\begin{array}{c}\text { Number of } \\
\text { polyspermic } \\
\text { oocytes } \\
(\%)^{c}\end{array}$} \\
\hline & & Total $(\%)$ & $\begin{array}{l}\text { With swollen } \\
\text { sperm head }\end{array}$ & $\begin{array}{c}\text { With male } \\
\text { and female } \\
\text { pronuclei }(\%)^{c}\end{array}$ & \\
\hline OKA-3 & 69 & $56(81)^{d}$ & 25 & $3 I(55)^{\mathrm{d}}$ & $19(34)$ \\
\hline $\mathrm{L}-4$ & 65 & $26(40)^{\mathrm{e}}$ & 12 & $14(54)^{\mathrm{d}}$ & $7(27)$ \\
\hline OKA-5 & 86 & $70(81)^{d}$ & 53 & $17(24)^{e}$ & $23(33)$ \\
\hline
\end{tabular}

${ }^{\mathrm{a}}$ The fertilization medium (mBO medium) contained $45.83 \mathrm{mmol} \mathrm{NaHCO}_{3} \mathrm{l}^{-1}, 5 \mathrm{mmol}_{\text {caffeine }} \mathrm{l}^{-1}$, and $1 \mathrm{mg} \mathrm{PVA} \mathrm{ml}{ }^{-1}$; the final sperm concentration was $8 \times 10^{6}$ cells $\mathrm{ml}^{-1}(n=3$ for each boar).

${ }^{\mathrm{b}}$ Oocytes were examined $14 \mathrm{~h}$ after insemination.

cPercentage of penetrated oocytes.

deValues with different superscripts within each column differ significantly $(P<0.05)$.

as described above just before fixation at each time of examination $(n=3)$.

The first evidence of sperm penetration was observed 4 and $6 \mathrm{~h}$ after insemination in cumulus-enclosed $(33 \%)$ and cumulusfree $(20 \%)$ oocytes, respectively (Table 5 ). Penetration rates gradually increased, reaching maximum values after a further $6 \mathrm{~h}: 95 \%$ of cumulus-enclosed oocytes penetrated at $10 \mathrm{~h}$ and $83 \%$ of cumulus-free oocytes penetrated at $12 \mathrm{~h}$. The incidence of polyspermy in cumulus-free oocytes was fairly constant throughout the period of assessment $(24-41 \%)$, but increased significantly $(P<0.05)$ in cumulus-enclosed oocytes with time, reaching the maximum value of $86 \%$ at $12 \mathrm{~h}$ after insemination. The proportions of penetrated, pronuclear stage, and polyspermic oocytes were significantly higher $(P<0.05)$ in cumulus-enclosed than cumulus-free oocytes at all times observed.

Experiment 6: time-dependent changes in motility, vitality and chlortetracycline patterns

Spermatozoa were incubated for $6 \mathrm{~h}$ without oocytes in the conditions detailed in Expt 4 and assessed at selected intervals.
However, in this experiment, multiple aliquots $(500 \mu \mathrm{l})$ of sperm suspension were incubated in $1.5 \mathrm{ml}$ polypropylene microcentrifuge tubes without covering paraffin oil and cap. Motility estimates were made on a small drop of sperm suspension under a cover slip using a bright-field microscope $(\times 100)$ equipped with a heated microwarm plate $\left(39^{\circ} \mathrm{C}\right.$; MP 10-DM, Kitazato Supply Co., Shizuoka). Sperm vitality was determined using bis-benzimide staining of 100 CTC-treated spermatozoa in each sample. CTC staining patterns were classified using 100 live spermatozoa in each sample. In the first series of experiments, time-dependent changes in motility, vitality and CTC patterns of spermatozoa from one boar (OKA-5) incubated in the presence and absence of $1 \mathrm{mg}$ PVA $\mathrm{ml}^{-1}$ were examined $(n=3)$. In the second series of experiments, time-dependent changes in these parameters were compared using spermatozoa from three boars (OKA-3, L-4 and OKA-5) in the medium containing $1 \mathrm{mg}$ PVA ml $\mathrm{ml}^{-1}$ $(n=3)$.

Using spermatozoa from boar OKA-5, sperm motility gradually decreased over the $6 \mathrm{~h}$ incubation (Fig. 2a); despite this, no significant decrease was observed in the percentage of 
Table 5. Time of penetration of cumulus-enclosed and cumulus-free pig oocytes in vitro by frozen-thawed ejaculated spermatozoa from boar OKA-5 ${ }^{\mathrm{a}}$

\begin{tabular}{|c|c|c|c|c|c|c|}
\hline \multirow{2}{*}{$\begin{array}{l}\text { Time of } \\
\text { after } \\
\text { insemination } \\
\text { (h) }\end{array}$} & \multirow[b]{2}{*}{$\begin{array}{c}\text { Presence }(+) \\
\text { or absence }(-) \\
\text { of cumulus }\end{array}$} & \multirow[b]{2}{*}{$\begin{array}{c}\text { Number of } \\
\text { oocytes } \\
\text { inseminated }\end{array}$} & \multicolumn{3}{|c|}{ Number of oocytes penetrated } & \multirow{2}{*}{$\begin{array}{c}\text { Number of } \\
\text { polyspermic } \\
\text { oocytes } \\
(\%)^{b}\end{array}$} \\
\hline & & & Total $(\%)$ & $\begin{array}{c}\text { With } \\
\text { swollen } \\
\text { sperm head }\end{array}$ & $\begin{array}{c}\text { With male } \\
\text { and female } \\
\text { pronuclei }(\%)^{b}\end{array}$ & \\
\hline \multirow[t]{2}{*}{2} & + & 41 & $0(0)^{c}$ & - & - & - \\
\hline & - & 39 & $0(0)^{c}$ & - & - & - \\
\hline \multirow[t]{2}{*}{4} & + & 39 & $13(33)^{\mathrm{de}}$ & 13 & $0(0)^{c}$ & $4(31)^{\mathrm{cd}}$ \\
\hline & - & 40 & $0(0)^{c}$ & - & - & - \\
\hline \multirow[t]{2}{*}{6} & + & 40 & $26(65)^{\mathrm{fg}}$ & 26 & $0(0)^{c}$ & $10(39)^{\mathrm{cd}}$ \\
\hline & - & 41 & $8(20)^{d}$ & 8 & $0(0)^{c}$ & $2(25)^{c}$ \\
\hline \multirow[t]{2}{*}{8} & + & 40 & $31(78)^{g}$ & 26 & $5(16)^{\text {de }}$ & $21(68)^{e}$ \\
\hline & - & 45 & $21(47)^{\mathrm{ef}}$ & 21 & $0(0)^{c}$ & $5(24)^{c}$ \\
\hline \multirow[t]{2}{*}{10} & + & 39 & $37(95)^{\mathrm{i}}$ & 30 & $7(19)^{\mathrm{de}}$ & $25(68)^{e}$ \\
\hline & - & 40 & $24(58)^{f}$ & 24 & $0(0)^{c}$ & $6(25)^{c}$ \\
\hline \multirow[t]{2}{*}{12} & + & 42 & $4 I(95)^{i}$ & 15 & $26(63)^{f}$ & $37(86)^{\mathrm{f}}$ \\
\hline & - & 39 & $32(83)^{\mathrm{gh}}$ & 28 & $4(13)^{d}$ & $13(41)^{d}$ \\
\hline \multirow[t]{2}{*}{14} & + & 35 & $34(97)^{i}$ & 10 & $24(71)^{f}$ & $28(82)^{f}$ \\
\hline & - & 44 & $35(80)^{g h}$ & 25 & $10(29)^{\mathrm{g}}$ & $12(34)^{\mathrm{cd}}$ \\
\hline
\end{tabular}

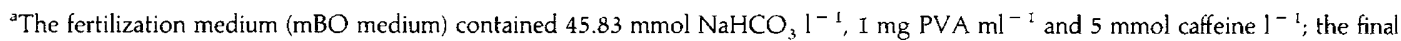
sperm concentration was $8 \times 10^{6}$ cells $\mathrm{ml}^{-1}(n=3)$.

'Percentage of penetrated oocytes.

cdefghivalues with different superscripts within each column differ significantly $(P<0.05)$.
}

live spermatozoa. These changes were not affected by the presence or absence of PVA in the medium. Changes in the distribution of CTC fluorescence patterns were also unaffected by the presence of PVA (Fig. 2b). There was a rapid decline in the proportion of $\mathrm{F}$ pattern spermatozoa from a mean of $93 \%$ at $\mathrm{O} h$ to $44-46 \%$ at $1 \mathrm{~h}$, accompanied by a rise in AR pattern spermatozoa from $0 \%$ at $0 \mathrm{~h}$ to $38-40 \%$, at $1 \mathrm{~h}$; the proportion of $\mathrm{B}$ pattern spermatozoa increased from $7 \%$ at $\mathrm{O} h$ to $15-18 \%$ at $30 \mathrm{~min}$ and $20-23 \%$ at $2 \mathrm{~h}$. During the remainder of the incubation, no further changes occurred in the proportion of $F$ pattern cells, but from 2-6 there was a slow but steady decline in the proportion of $B$ pattern cells.

In suspensions from all three boars evaluated, sperm motility but not vitality had decreased significantly $(P<0.05)$ after $6 \mathrm{~h}$ (Table 6), with significant differences $(P<0.05)$ among the three boars being evident. Marked decreases and increases in the proportions of $\mathrm{F}$ and AR pattern spermatozoa, respectively, and only a comparatively slight increase in $B$ pattern spermatozoa were observed in all samples after incubation for $6 \mathrm{~h}$. Despite variability in motility and vitality among samples from the three boars, there were no significant differences in the values for CTC patterns before and after incubation.

\section{Discussion}

This is the first experimental study to report successful fertilization of in vitro matured cumulus-free pig oocytes by frozen-thawed ejaculated boar spermatozoa in a chemically defined, protein-free medium. Penetration rates were affected by a number of factors, especially the concentrations of spermatozoa and $\mathrm{NaHCO}_{3}$. In modified $\mathrm{BO}$ medium contain- ing $37.0 \mathrm{mmol} \mathrm{NaHCO}_{3} \mathrm{l}^{-1}, 5 \mathrm{mmol}$ caffeine $\mathrm{l}^{-1}$ and $1 \mathrm{mg}$ PVA $\mathrm{ml}^{-1}$, the penetration rates were low $(<50 \%)$ and influenced by the sperm concentration: $44-45 \%$ oocytes pen-

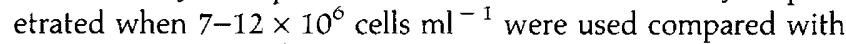

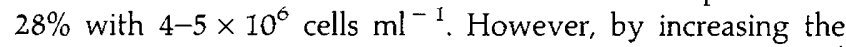
$\mathrm{NaHCO}_{3}$ concentration of the medium and using 7-8 $\times 10^{6}$ cells $\mathrm{ml}^{-1}$, these poor penetration rates were much improved, reaching $76 \%$ with $45.83 \mathrm{mmol} \mathrm{NaHCO}_{3} \mathrm{l}^{-1}$. A similar result has been obtained with cumulus-free bovine oocytes inseminated in a defined medium containing PVA (Tajik et al., 1994).

Although Hyne (1984) suggested that $\mathrm{NaHCO}_{3}$ functions as a buffering component for guinea-pig spermatozoa to undergo the acrosome reaction, in the present study the $\mathrm{pH}$ was quite constant $(7.7 \pm 0.03)$ over the range of $\mathrm{NaHCO}_{3}$ concentrations used $\left(37.0-50.25 \mathrm{mmol} \mathrm{l}^{-\mathrm{I}}\right)$. This may indicate that $\mathrm{NaHCO}_{3}$ has a role other than as a $\mathrm{pH}$-buffering molecule. Bicarbonate maintains the motility of caput and caudal bovine spermatozoa by acting to increase the intracellular $\mathrm{pH}$ (Vijayaraghavan et al., 1985). It is also reported to play an important role in hyperactivation of mouse (Neill and OldsClarke, 1987), guinea-pig (Bhattacharyya and Yanagimachi, 1988), and hamster (Boatman and Robbins, 1991) spermatozoa. Bicarbonate stimulates mammalian sperm adenylate cyclase (Okamura et al., 1985; Garty and Salomon, 1987; Tajima et al., 1987) and hence production of CAMP; CAMP promotes sperm motility and fertilizing ability in many species (reviewed by Fraser and Monks, 1990). In mice, it was suggested that $\mathrm{NaHCO}_{3}$ is necessary for the $\mathrm{Ca}^{2+}$ influx into spermatozoa (Lee and Storey, 1986) and its concentration may be critical for supporting the acrosome reaction (Neill and Olds-Clarke, 1987). Suzuki et al. (1994) provided evidence that bicarbonate 
(a)

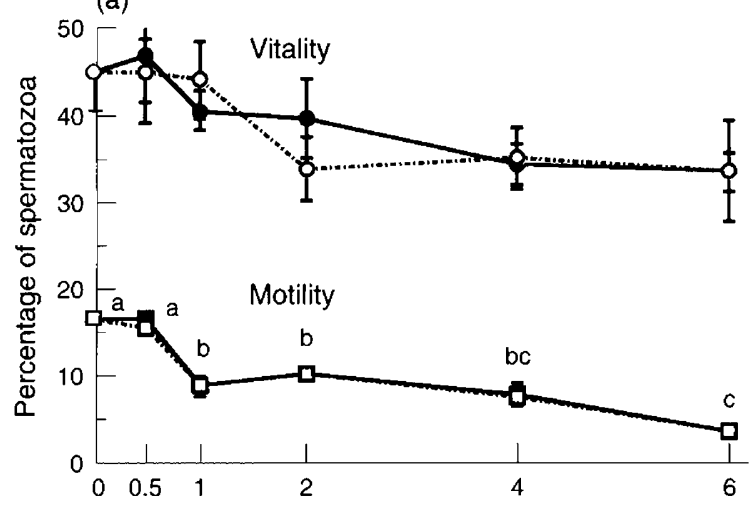

(b)

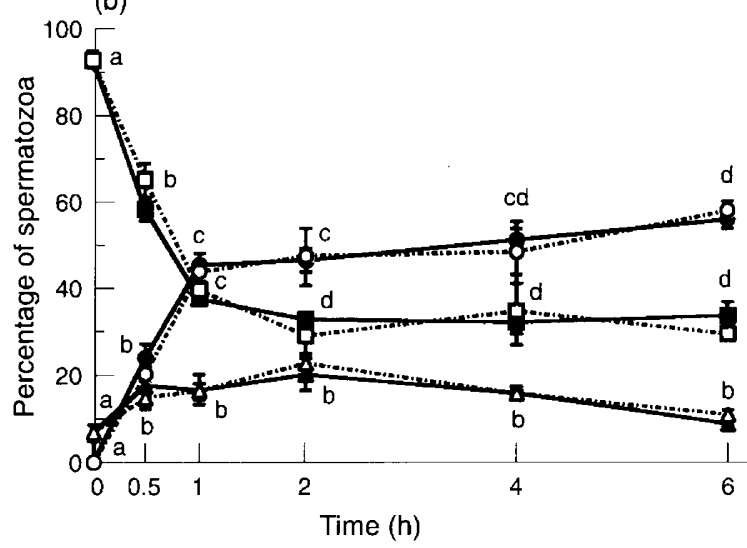

Fig. 2. Time-dependent changes in (a) motility and vitality, and (b) chlortetracycline (CTC) fluorescence patterns in spermatozoa (from one boar; OKA-5) incubated for $6 \mathrm{~h}$ in $\mathrm{mBO}$ medium containing $45.83 \mathrm{mmol} \mathrm{NaHCO}_{3} \mathrm{I}^{-1}$ and $5 \mathrm{mmol}$ caffeine $\mathrm{I}^{-1}$ in the absence (open symbols) or presence (closed symbols) of $1 \mathrm{mg} \mathrm{PVA} \mathrm{ml}^{-1}$. Each point represents the mean $( \pm \mathrm{SE})$ of three replicates. The CTC patterns (b) represent $\mathrm{F}(\sqsubset, \boldsymbol{\square}), \mathrm{B}(\Delta, \mathbf{\Delta})$, and $\mathrm{AR}(\mathrm{\sigma}, \bullet)$. Values with different letters within each parameter differ significantly $(P<0.05)$.

promotes fertilization of pig oocytes in vitro primarily through effects on spermatozoa rather than oocytes. Consistent with this conclusion, Harrison et al. (1993), using flow cytometry, observed an early, large influx of $\mathrm{Ca}^{2+}$ into boar spermatozoa when bicarbonate is present. They suggested that this membrane destabilization represents an early step in capacitation. These findings suggest that changes in sperm intracellular $\mathrm{pH}$, $\mathrm{Ca}^{2+}$ and cAMP occur during incubation in media containing higher concentrations of $\mathrm{NaHCO}_{3}$, thereby promoting sperm motility and capacitation.

In the present study, using caffeine-containing protein-free $\mathrm{mBO}$ medium, sperm motility, vitality and fertilizing ability were similar in both the presence and absence of PVA. In contrast, Tajik et al. (1994) reported penetration of cumulus-free bovine oocytes in protein-free, caffeine- and heparin-containing media only when PVA was included. In other species, PVA has proved unable to support fertilization in vitro (hamsters: Bavister, 1981; mice: Fraser, 1985; cattle: Parrish et al., 1989). Caffeine has an essential role for either inducing capacitation of frozen-thawed ejaculated boar spermatozoa or promoting penetration of cumulus-enclosed oocytes in medium with FCS (Wang et al., 1991). Although experiments in which both caffeine and PVA were omitted were not performed in the present study, penetration of oocytes and time-dependent changes in motility, vitality and the CTC patterns of boar spermatozoa were not altered by the presence or absence of PVA. Therefore, it appears that caffeine, in the absence of any macromolecule, is sufficient to support all the changes required for complete boar sperm function.

The results indicating variations in penetration rates among sperm suspension from three boars are consistent with earlier reports (Nagai et al., 1988; Wang et al., 1991; Vázquez et al., 1993). Vázquez et al. (1993) reported no correlation between penetration rates and the percentages of acrosome-reacted spermatozoa, but other variables, such as sperm motility and an ability of spermatozoa to bind to an oocyte may be important (e.g., Wang et al., 1991). Of the three boars compared in the present study, spermatozoa from one (boar L-4) showed a lower penetrability $(40 \%)$, motility and vitality, compared with those from the other two boars. Despite this, suspensions from all three had similar, high proportions of AR pattern cells when assessed with CTC after $6 \mathrm{~h}$ incubation.

In the present study, it took 4 and $6 \mathrm{~h}$ for frozen-thawed ejaculated boar spermatozoa to start penetrating cumulusenclosed and cumulus-free oocytes, respectively, in protein-free medium containing caffeine and PVA. When medium supplemented with $1 \mathrm{mg} \mathrm{BSA} \mathrm{ml}{ }^{-1}$ instead of PVA was used, penetration of cumulus-free oocytes began $4 \mathrm{~h}$ after insemination (W. H. Wang and K. Niwa, unpublished). These results are consistent with those of Ding et al. (1992), who reported that fresh ejaculated spermatozoa, preincubated for $1.5 \mathrm{~h}$ in $\mathrm{BO}$ medium with $10 \mathrm{mg} \mathrm{BSA} \mathrm{ml}^{-1}$, take $4 \mathrm{~h}$ to start penetrating cumulus-enclosed oocytes. Although it is not known precisely how cumulus cells or BSA facilitate penetration of oocytes, there is evidence that cumulus cells can induce the acrosome reaction of human (Sullivan et al., 1990) and bovine (Fukui, 1990) spermatozoa.

During incubation of mouse (Fraser and McDermott, 1992), human (DasGupta et al., 1993) and bovine (Fraser et al., 1995) sperm suspensions under conditions known to support capacitation and fertilization in vitro, there are changes in the distribution of the three CTC fluorescence patterns, with a sequential alteration from the $\mathrm{F}$ to the $\mathrm{B}$ pattern and then to the AR pattern. These changes in CTC patterns provide information on the functional state of spermatozoa: the F pattern is characteristic of uncapacitated, acrosome intact cells; the B pattern characteristic of capacitated, acrosome-intact cells; and the AR pattern characteristic of acrosome-reacted cells. In the present study, these three distinct patterns, which were essentially the same as those described for both fresh and frozenthawed bull spermatozoa (Fraser et al., 1995), were observed consistently in frozen-thawed ejaculated boar spermatozoa incubated in mBO medium containing $45.83 \mathrm{mmol} \mathrm{NaHCO}_{3}$ $1^{-1}, 5 \mathrm{mmol}$ caffeine $\mathrm{l}^{-1}$ and $1 \mathrm{mg}$ PVA ml ${ }^{-1}$. When CTC patterns were examined during incubation for $6 \mathrm{~h}$ in media with and without PVA, a rapid decrease in the proportion of $F$ and a rapid increase in the proportion of AR pattern spermatozoa were observed over the first hour. Thereafter, although little change in $\mathrm{F}$ pattern cells was noted, there was a slight but steady increase in the proportion of AR pattern cells during the remaining $5 \mathrm{~h}$. The proportion of $\mathrm{B}$ pattern spermatozoa significantly increased during the first $2 \mathrm{~h}$, and then slowly but 
Table 6. Changes in motility, vitality and chlortetracycline (CTC) fluorescence patterns in spermatozoa obtained from three different boars $^{a}$

\begin{tabular}{|c|c|c|c|c|c|c|c|c|c|c|}
\hline \multirow[b]{3}{*}{ Boar } & \multirow{2}{*}{\multicolumn{2}{|c|}{$\begin{array}{c}\text { Percentage of motile } \\
\text { spermatozoa (mean } \pm \mathrm{SE})\end{array}$}} & \multirow{2}{*}{\multicolumn{2}{|c|}{$\begin{array}{c}\text { Percentage of live } \\
\text { spermatozoa (mean } \pm \mathrm{SE})\end{array}$}} & \multicolumn{6}{|c|}{ CTC patterns $(\% \text {, mean } \pm \mathrm{sE})^{\mathrm{b}}$} \\
\hline & & & & & \multicolumn{2}{|c|}{$\mathrm{F}$} & \multicolumn{2}{|r|}{ B } & \multicolumn{2}{|c|}{ AR } \\
\hline & $\mathrm{Oh}$ & $6 \mathrm{~h}$ & $\mathrm{oh}$ & $6 \mathrm{~h}$ & $\mathrm{Oh}$ & $6 \mathrm{~h}$ & $\mathrm{Oh}$ & $6 \mathrm{~h}$ & $\mathrm{Oh}$ & $6 \mathrm{~h}$ \\
\hline OKA-3 & $20.7 \pm 0.8^{\mathrm{c}}$ & $8.7 \pm 0.8^{c *}$ & $56.0 \pm 3.1^{c}$ & $52.7 \pm 2.9^{\circ}$ & $92.0 \pm 2.5$ & $39.0 \pm 6.3^{*}$ & $7.7 \pm 2.9$ & $10.3 \pm 1.1^{*}$ & $0.3 \pm 0.4$ & $52.7 \pm 7.4^{*}$ \\
\hline L-4 & $8.0 \pm 0.7^{\mathrm{d}}$ & $1.7 \pm 0.8^{\mathrm{d} *}$ & $33.0 \pm 5.8^{\mathrm{d}}$ & $24.0 \pm 3.1^{\mathrm{d}}$ & $89.0 \pm 0.7$ & $42.3 \pm 2.9^{*}$ & $8.7 \pm 1.1$ & $14.4 \pm 1.5^{*}$ & $2.3 \pm 0.8$ & $47.0 \pm 2.5^{*}$ \\
\hline OKA-5 & $18.0 \pm 1.4^{\mathrm{c}}$ & $4.7 \pm 0.8^{\mathrm{e} *}$ & $44.0 \pm 3.7^{\mathrm{cd}}$ & $38.0 \pm 1.9^{\mathrm{e}}$ & $93.3 \pm 1.8$ & $34.7 \pm 2.2^{*}$ & $6.7 \pm 1.8$ & $12.0 \pm 1.9^{*}$ & $0.0 \pm 0.0$ & $53.3 \pm 4.0^{*}$ \\
\hline
\end{tabular}

${ }^{a}$ Spermatozoa were incubated for $6 \mathrm{~h}$ in mBO medium containing $45.83 \mathrm{mmol} \mathrm{NaHCO} \mathrm{l}^{-1}, 5 \mathrm{mmol}$ caffeine $\mathrm{l}^{-1}$ and $1 \mathrm{mg} \mathrm{PVA} \mathrm{ml}{ }^{-1}(n=3$ for each boar).

${ }^{\mathrm{b}}$ The percentage of different CTC patterns refer to live spermatozoa only.

${ }^{c d e}$ Values with different superscripts within each column differ significantly $(P<0.05)$.

*For each parameter in each boar, the value is significantly different from that at $0 \mathrm{~h}(P<0.05)$.

steadily declined. These results indicate that capacitation and spontaneous acrosome reaction occur rapidly in most spermatozoa incubated in this chemically defined medium. However, it appears that these cells undergoing early spontaneous acrosome reaction may not be involved in penetrating oocytes, since the first evidence of sperm penetration in cumulus-free oocytes was not observed until $6 \mathrm{~h}$ after insemination in the present experimental conditions. The rapid acrosomal exocytosis that occurs in almost half of the cells within the first hour of incubation probably indicates that many cells have been damaged during freezing and thawing and therefore are functionally compromised. This would be consistent with the discrepancies between the proportions of live and actively motile cells in a suspension, the latter being markedly lower than the former. These observations may explain, at least in part, the generally low fertilization rates obtained after artificial insemination of sows with frozen-thawed spermatozoa. The functionally competent fertilizing cells would be drawn from the small pool of spermatozoa that retain motility and gradually undergo capacitation, acquiring the ability to undergo an acrosome reaction upon interaction with oocytes.

In the present study, more than $80 \%$ of cumulus-free oocytes were penetrated in $\mathrm{mBO}$ medium containing $45.83 \mathrm{mmol}$ $\mathrm{NaHCO}_{3} \mathrm{l}^{-1}, 5 \mathrm{mmol}$ caffeine $\mathrm{l}^{-1}$ and $1 \mathrm{mg} \mathrm{PVA} \mathrm{ml}{ }^{-1}$ when spermatozoa from boars of high fertility were used. Despite this, the incidence of polyspermic oocytes was kept comparatively low $(33-36 \%)$. If it can be demonstrated that the incidence of male pronuclear formation increases during a more extended culture period than that of $14 \mathrm{~h}$ used in this study, then the present system using a chemically defined, protein-free medium might provide a successful approach for obtaining normal pig embryos by in vitro fertilization.

In conclusion, this is the first report that in vitro matured cumulus-free pig oocytes can be penetrated by frozen-thawed ejaculated spermatozoa in a chemically defined, protein-free medium. Capacitation and spontaneous acrosome reactions occur rapidly in many cells, but these cells appear to be non-fertilizing and probably have been damaged by freezing and thawing. The fertilizing spermatozoa appear to capacitate more slowly. This system could be useful for analysing more rigorously the factors necessary both for the acquisition of sperm functional competence and for normal cytoplasmic maturation leading to normal monospermic pronuclear formation following in vitro fertilization of pig oocytes.

This work was supported by Grant-in-Aid for Encouragement of the Japan Society for the Promotion of Science (JSPS) Fellowship for Japanese Junior Scientists from the Ministry of Education, Science and Culture of Japan. W. H. Wang is a recipient of the JSPS Fellowship (No. 0361). L. R. Fraser was a recipient of the JSPS Fellowship for research in Japan.

\section{References}

Bavister BD (1981) Substitution of a synthetic polymer for protein in a mammalian gamete culture system Journal of Experimental Zoology 217 $45-51$

Bavister BD (1982) Evidence for a role of post-ovulatory cumulus components in supporting fertilizing ability of hamster spermatozoa Journal of Andrology $3365-372$

Bhattacharyya A and Yanagimachi R (1988) Synthetic organic pH buffers can support fertilization of guinea pig eggs, but not as efficiently as bicarbonate buffer Gamete Research 19 123-129

Boatman DE and Robbins RS (1991) Bicarbonate:carbon-dioxide regulation of sperm capacitation, hyperactivated motility, and acrosome reactions Biology of Reproduction 44 806-813

Brackett BG and Oliphant G (1975) Capacitation of rabbit spermatozoa in vitro Biology of Reproduction 12 260-274

DasGupta S, Mills CL and Fraser LR (1993) $\mathrm{Ca}^{2+}$-related changes in the capacitation state of human spermatozoa assessed by a chlortetracycline fluorescence assay Journal of Reproduction and Fertility 99 135-143

Ding J, Clarke N, Nagai T and Moor RM (1992) Protein and nuclear changes in pig eggs at fertilization Molecular Reproduction and Development 31 287-296

Fraser LR (1985) Albumin is required to support the acrosome reaction but not the capacitation in mouse spermatozoa in vitro Journal of Reproduction and Fertility 74 185-196

Fraser LR and McDermott CA (1992) $\mathrm{Ca}^{2+}$-related changes in the mouse sperm capacitation state: a possible role for $\mathrm{Ca}^{2+}$-ATPase Journal of Reproduction and Fertility $96363-377$

Fraser LR and Monks NJ (1990) Cyclic nucleotides and mammalian sperm capacitation Journal of Reproduction and Fertility Supplement 42 9-12

Fraser LR, Abeydeera LR and Niwa K (1995) $\mathrm{Ca}^{2+}$-regulating mechanisms that modulate bull sperm capacitation and acrosomal exocytosis as determined by chlortetracycline analysis Molecular Reproduction and Development $\mathbf{4 0}$ 233-241

Fukui Y (1990) Effect of follicle cells on the acrosome reaction, fertilization, and developmental competence of bovine oocytes matured in vitro Molecular Reproduction and Development 26 40-46

Funahashi H and Day BN (1993a) Effects of different serum supplements in maturation medium on meiotic and cytoplasmic maturation of pig oocytes Theriogenology 39 965-973 
Funahashi H and Day BN (1993b) Effects of follicular fluid at fertilization in vitro on sperm penetration in pig oocytes Journal of Reproduction and Fertility 99 97-103

Garty BN and Salomon Y (1987) Stimulation of partially purified adenylate cyclase from bull sperm by bicarbonate FEBS Letters 218 148-152

Harrison RAP, Mairet B and Miller NGA (1993) Flow cytometric studies of bicarbonate-mediated $\mathrm{Ca}^{2+}$ influx in boar sperm populations Molecular Reproduction and Development 35 197-208

Hyne RV (1984) Bicarbonate- and calcium-dependent induction of rapid guinea pig sperm acrosome reactions by monovalent ionophores Biology of Reproduction 31 312-323

Kikuchi K, Nagai T, Motlik J, Shioya Y and Izaike Y (1993) Effect of follicle cells on in vitro fertilization of pig follicular oocytes Theriogenology 39 593-599

Lee MA and Storey BD (1986) Bicarbonate is essential for fertilization of mouse eggs: mouse sperm requires to undergo the acrosome reaction Biology of Reproduction 34 349-356

Nagai T, Takahashi T, Masuda H, Shioya Y, Kuwayama M, Fukushima M, Iwasaki $\mathrm{S}$ and Hanada A (1988) In vifro fertilization of pig oocytes by frozen boar spermatozoa Journal of Reproduction and Fertility 84 585-591

Neill JM and Olds-Clarke P (1987) A computer-assisted assay for mouse sperm hyperactivation demonstrates that bicarbonate but not bovine serum albumin is required Gamete Research 18 121-140

Okamura N, Tajima Y, Soejima A, Masuda H and Sugita Y (1985) Sodium bicarbonate in seminal plasma stimulates the motility of mammalian spermatozoa through direct activation of adenylate cyclase Journal of Biological Chemistry 260 9699-9705

Parrish JJ, Susko-Parrish J and First NL (1989) Capacitation of bovine sperm by heparin: inhibitory effect of glucose and role of intracellular $\mathrm{pH}$ Biology of Reproduction 42 683-699

Sullivan R, Duchesne C, Fahmy N, Morin N and Dionne P (1990) Protein synthesis and acrosome reaction-inducing activity of human cumulus cells Human Reproduction 5 830-834

Suzuki K, Ebihara M, Nagai T, Clarke NGE and Harrison RAP (1994) Importance of bicarbonate $/ \mathrm{CO}_{2}$ for fertilization of pig oocytes in vitro, and synergism with caffeine Reproduction. Fertility and Development 6 221-227
Tajik P, Niwa K and Murase T (1993) Effects of different protein supplements in fertilization medium on in vitro penetration of cumulus-intact and cumulusfree bovine oocytes matured in culture Theriogenology 40 949-958

Tajik P, Wang WH, Okuda K and Niwa K (1994) In vitro penetration of bovine oocytes in a chemically defined, protein-free medium varying the bicarbonate concentration Biology of Reproduction 50 1231-1237

Tajima Y, Okamura N and Sugita $Y$ (1987) The activating effect of bicarbonate on sperm motility and respiration at ejaculation Biochimica et Biophysica Acta $924519-529$

Vázquez JM, Martinez E, Roca J, Coy P and Pastor LM (1993) Acrosome reaction of boar spermatozoa in homologous in vitro fertilization Molecular Reproduction and Development 36 84-88

Vijayaraghavan S, Critchlow LM and Hoskins DD (1985) Evidence for a role for cellular alkalinization in the cyclic adenosine $3^{\prime}, 5^{\prime}$-monophosphate-mediated initiation of motility in bovine caput spermatozoa Biology of Reproduction 32 489-500

Wang WH, Niwa K and Okuda K (1991) In vitro penetration of pig oocytes matured in culture by frozen-thawed ejaculated spermatozoa Journal of Reproduction and Fertility 93 491-496

Wang WH, Uchida M and Niwa K (1992) Effects of follicle cells on in vitro penetration of pig oocytes by cryopreserved, ejaculated spermatozoa Journal of Reproduction and Development 38 125-131

Wang WH, Abeydeera LR, Okuda K and Niwa K (1994) Penetration of porcine oocytes during maturation in vitro by cryopreserved, ejaculated spermatozoa Biology of Reproduction 50 510-515

Ward CR and Storey BT (1984) Determination of the time course of capacitation in mouse spermatozoa using a chlortetracycline fluorescence assay Developmental Biology 104 287-296

Yoshida M, Mizoguchi Y, Ishigaki K, Kojima T and Nagai T (1993) Birth of piglets derived from in vitro fertilization of pig oocytes matured in vitro Theriogenology 39 1303-1311

Zheng YS, Fiser P and Sirard MA (1992) The use of ejaculated boar semen after freezing in 2 or $6 \%$ glycerol for in vitro fertilization of porcine oocytes matured in vitro Theriogenology 38 1065-1075 